\title{
KONFERENCIA BESZÁMOLÓ \\ AZ I. KÜLÖNLEGES BÁNÁSMÓD NEMZETKÖZI KONFERENCIÁRÓL
}

(Hajdúböszörmény, 2015. december.3.)

\section{Szerző:}

Mező Katalin

Debreceni Egyetem

Szerző e-mail címe:

mezo.katalin@ped.unideb.hu

Mező Katalin (2015): Konferencia beszámoló az I. Különleges Bánásmód Nemzetközi Konferenciáról. Hajdúböszörmény, 2015.12.03. Különleges Bánásmód, I. évf. 2015/1. szám, 105-108. DOI 10.18458/KB.2015.1.105

Nagy érdeklődésre tartott számot a 2015. december 3-án, a Debreceni Egyetem Gyermeknevelési és Felnőttképzési Karán (DE GYFK) megrendezésre került I. Különleges Bánásmód Nemzetközi Konferencia, melyet a Pszichológiai és Gyógypedagógiai Tanszék szervezett meg (1. kép).

1. kép: az I. Különleges Bánásmód Nemzetközi Konferencia (Hajdúböszörmény, 2015. december 3.)

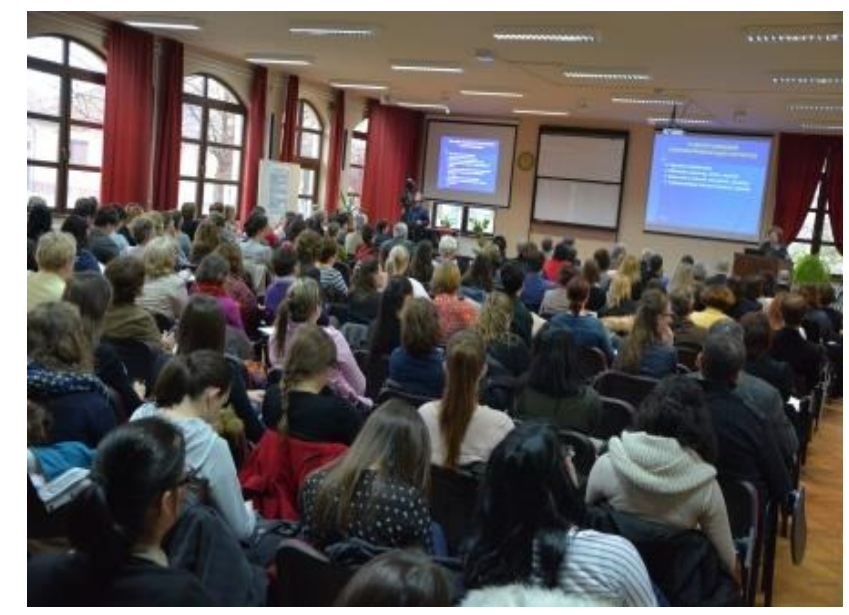

A rendezvény célja, hogy bemutassa a különleges bánásmóddal élök (sajátos nevelési igényüek; beilleszkedési, tanulási magatartási zavarokkal küzdők; kiemelten tehetségesek) fejlesztésével foglalkozó elméleti és gyakorlati kutatások legújabb eredményeit. A konferencia időzítésének apropója: 
1) december harmadikát az ENSZ 1992-ben a fogyatékos emberek világnapjává nyilvánította, azzal a céllal, hogy felhívja a figyelmet a baleset, betegség, katasztrófa következtében fogyatékkal élővé váltak problémáira. A rendezvény ennek a napnak a méltó képviseletéhez járult hozzá.

2) a hajdúböszörményi DE GYFK hamarosan gyógypedagógiai szak indítására készül, ennek előzményeként, hírvivőuil, eddigi eredményeink, kutatásaink megismertetése céljából szerveződött a konferencia.

3) Különleges Bánásmód címú új, interdiszciplináris szakmai folyóirat bemutatására is sor került a rendezvényen.

A konferencia megnyitó beszédét a Debreceni Egyetem képviseletében Prof. Dr. Csernoch László tudományos rektorhelyettes tartotta: „Az oktatás egyik legfontosabb feladata az érdeklődés felkeltése mindenkiben, így azokban is, akik akár biológiai, akár társadalmi okok miatt kerültek hátrányos helyzetbe. Mi az egyetemen tudjuk: ennek eléréséhez szükség van olyan jól képzett pedagógusokra, akik tudják, hogyan lehet a különböző fogyatékkal élőket is eredményesen oktatni" mondta köszöntőjében.

Majd ezt követően Kiss Attila, Hajdúböszörmény Polgármestere, valamint Prof. Dr. Bálint Péter, a Gyermeknevelési és Felnőttképzési Kar Dékánja köszöntötte a konferencia résztvevőit.

A nemzetközi tanácskozásra hazánkon kívül nyolc országból (Anglia, Ausztrália, Szerbia, Románia, Szlovákia, Ukrajna, Csehország, Szlovénia) érkeztek résztvevők szakmai tapasztalatcserére. A konferencián 4 plenáris előadás hangzott el, majd 112 fő hazai és nemzetközi szekcióelőadó tartott előadást 11 szekcióban.

A plenáris előadások (2. kép) közül az elsőt Prof. Dr. Mesterházi Zsuzsa professzor emeritus tartotta „A hazai gyógypedagógia tudományos mühelyei, elméletképzési irányzatai” címmel. Az előadás során az elméleti alapfelvetés európai kezdetei után a hazai gyógypedagógiai kialakulását megalapozó mühelyek - kísérleti pszichológia alkalmazása Ranschburg Pál laboratóriumában; az intelligencia mérése Éltes Mátyás mühelyében) kerültek bemutatásra.

2. kép: az I. Különleges Bánásmód Nemzetközi Konferencia (Hajdúböszörmény, 2015. 12.03) plenáris előadói és a szervezői balról jobbra: Dr. Mező Ferenc, Prof. Dr. Mesterházi Zsuzsa, Prof. Dr. Varga Imre, Mezö Katalin, Prof. Dr. Nagy Dénes, Dr. Szilágyi Barnabás, Dr. Szabó Edina, Dr. Dankovics Natália

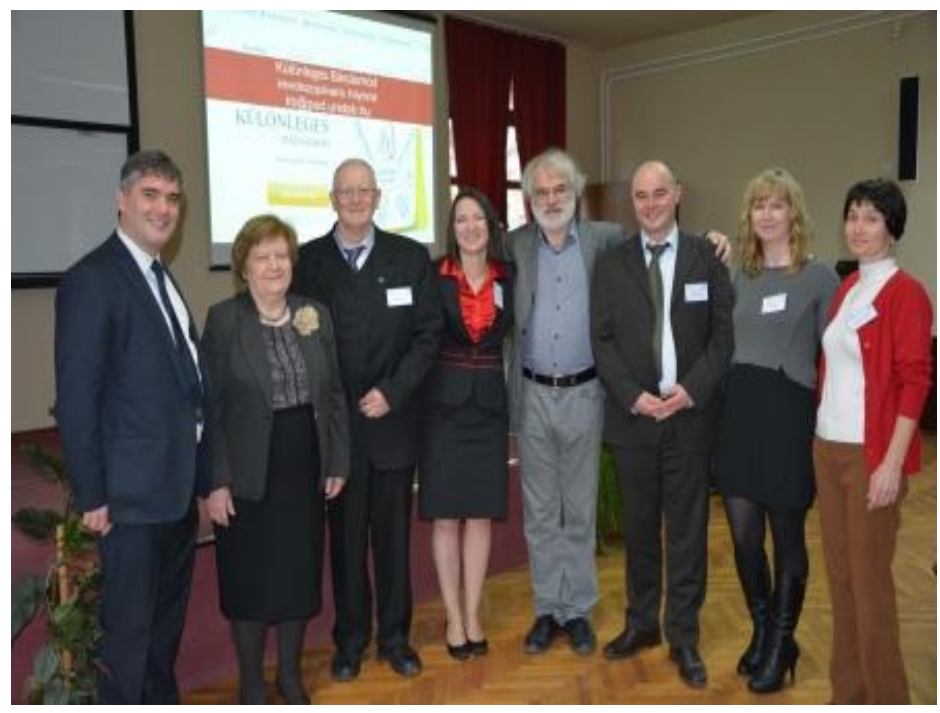


A professzorasszony előadásában ezt követően a hazai gyógypedagógia megalapozóinak (Dr. Tóth Zoltán, Dr. Vértes O. József, Dr. Bárczi Gusztáv) munkássága került méltatásra. Emellett bemutatásra kerültek a gyógypedagógia legjelentősebb személyiségei: 1) a gyógypedagógiai pszichológia megala-pozója, Ilyés Gyuláné dr. Kozmutza Flóra, akinek öröksége olyan empirikus diagnosztikus eszközök, vizsgáló eljárások (tesztek) megalkotása a fogyatékosságok megismerése és a fogyatékos gyermek/felnőtt nevelése, segítése céljából; melyeket a mai napig használnak a gyógyapedagógusok. 2) Dr. Göllesz Viktor a komplex gyógypedagógiai rehabilitáció képviselője. 3) Gordosné dr. Szabó Anna a gyógypedagógia leggyakrabban használt fogalmának megalkotója (a tágabb értelemben vett gyógypedagógia: a fogyatékos emberrel és a fogyatékosság jelenségével foglalkozó komplex tudomány (a forrásés határtudományok szerepe); a szükebb értelemben vett gyógypedagógia: a fogyatékos emberek nevelésének, terápiájának, rehabilitációjának elméletével és gyakorlatával foglalkozó tudomány, Gordosné, 1990, 44-56.). 4) Dr. Illyés Sándor, az empirikus és fenomenológiai kutatások képviselője, a gyógypedagógiai alapismeretek címü alapmü létrehozója. Majd ismertetésre kerültek a tágabb és szükebb értelemben vett gyógypedagógiai tudományterületek, különös tekintettel a speciális pedagógiákra. Záró gondolatként a résztvevők megismerhették napjaink hazai gyógypedagógiai mühelyeit és mindazokat a kutatási irányokat, amelyek a hazai kutató műhelyekben felszínre kerülnek.

Második előadóként Prof. Dr. Varga Imre a Szegedi Tudományegyetem címzetes főiskolai tanárának előadása hangzott el (társelőadó: Prof. Dr. Hatos Gyula címzetes főiskola tanár, aki nem tudott részt venni a rendezvényen, de szeretetteljes üdvözletét küldte a konferencia hallgatóságának). Az előadás címe: „Náray-Szabó Sándor reformtevékenysége és hatása a szegedi és debreceni gyógypedagógiai intézetekre". Az elöadásban a méltatlanul elfeledett Náray-Szabó Sándor életmüvének került sor, akinek hatása egyaránt érvényesül napjaink szegedi és debreceni gyógypedagógiai tevékenyégében is. Dr. Varga Imre beszélt: 1) A fogyatékos gyermekek iskoláztatásának megjelenéséről a magyar közoktatásban. 2) NáraySzabó Sándorról, mint reformerről a XIX. század végén. 3) A XX. századi magyar gyógypedagógia megalapozásáról. 4) A fogyatékos gyermekek, tanulók képzésének korszerüsítéséröl. 5) Az intézetek, iskolák müködésének és a gyógypedagógusok képzésének megújításáról. 6) A gyógypedagógiai intézetek, iskolák fejlődéséről. 7) Náray-Szabó Sándor munkásságának hatásáról Szeged és Debrecen oktatásügyére. 8) A fogyatékos személyekről szóló törvény tervezetéröl. 9) A gyógypedagógia népszerüsítéséröl. Náray-Szabó Sándor napjainkban is érvényes elveket és szemléletmódot alakított ki, mely elvek korszerüek és továbbvitelre érdemesek a modern gyógypedagógiában is.

A harmadik plenáris elöadást Prof. Dr. Nagy Dénes tartotta. Az ausztrál-magyar kutatóprofesszor alapító elnöke a Nemzetközi Szimmetria Társaságnak (1989), amely a tudomány és a müvészet képviselőinek együttmüködését segíti interdiszciplináris témákban, ideértve a müszaki és a társadalomtudományokat is. Dr. Nagy Dénes „A magyar teremtöképesség és a tudományköziség” címü előadásában a tudományterületek közötti „hidak" fontosságát hangsúlyozta. Véleménye szerint számos probléma megoldásához elengedhetetlen az interdiszciplináris gondolkodás melyben Magyarország nagyhatalom.

A negyedik plenáris előadást Dr. Mezö Ferenc a Pszichológiai és Gyógypedagógia Tanszék pszichológusa tartotta, aki a Különleges Bánásmód Interdiszciplináris Folyóirat alapító főszerkesztőjeként beszélt, a különleges bánásmód fogalmáról, a folyóirat céljáról, leendő tartalmairól, a multidiszciplinaritásról, a folyóirat elérhetőségéről (www.degyfk.hu/kulonleges banasmod).

A plenáris előadások ideje alatt kísérő rendezvényként zajlott a DEGYFK és a DEMEK közös szervezésében az 5. Esélyegyenlőségi Nap, ahol több mint 120 fö, főként hallgatókból álló csoport, érzékenyítő játékok formájában tapasztalhatta meg a különböző fogyatékossági 
problémákat és élethelyzeteket. Emelett sor került Teveliné Szilágyi Anita szájjal festő hallgató kiállításának megnyitására is.

A plenáris előadásokat követő rövid ebédszünet után 11 szekcióban osztódtak szét a résztvevők. A szekciók témái voltak:

1) Különleges Bánásmód: intézmények, kutatások a különleges bánásmód terén (szekcióvezető: Dr. Mező Ferenc).

2) Sajátos nevelési igény (Szekcióvezető: Mező Katalin).

3) Tehetség (Szekcióvezető: Sarka Ferenc).

4) Logopédia (Szekcióvezető: Dr. Szabó Edina).

5) Beilleszkedési, tanulási, magatartási zavar (Szekcióvezető: Dr. Szerepi Sándor).

6) A különleges bánásmód multikulturális és szociálpedagógiai vonatkozásai (Szekcióvezető: Dr. Gortka-Rákó Erzsébet).

7) Marginalizálódás és felzárkóztatás az oktatásban (Szekcióvezető: Dr. Bocsi Veronika).

8) Különleges bánásmód a munkaerőpiacon (Szekcióvezető: Dr. Móré Mariann).

9) A különleges bánásmód megjelenése a sportban és informatikában (Szekcióvezető: Dr. Molnár Balázs).

10) A különleges bánásmód és nyelvészet (Szekcióvezető: Dr. Schéder Veronika).

11) Angol nyelvü előadások (Szekcióvezető: Vargáné Dr. Nagy Anikó).

Külön örömünkre szolgált a Professzorok az Európai Magyarországért Egyesület fiatal tehetségeinek alkotó részvétele a szekcióüléseken.

A szekció előadások utáni összefoglalókban a vezetők arról számoltak be, hogy nagyon széleskörü és korszerü, újszerü kutatások léteznek a különleges bánásmód valamennyi területén, melyek beszámolói folyamatosan fognak megjelenni a Különleges Bánásmód folyóirat lapszámaiban.

Az I. Különleges Bánásmód Nemzetközi Konferencia képgalériája megtalálható az alábbi honlapon: http://www.degyfk.hu/kepgaleriak/category/193-kbnkonferencia 